\title{
The effect of first trimester hemoglobin levels on pregnancy
} outcomes

\section{İlk trimester hemoglobin seviyelerinin gebelik sonuçlarına etkisi}

\author{
(1) Burcu Dinçgez Çakmak, (1) Ülkü Ayşe Türker, (1) Sonay Öztaş, (D) Melis Arık, (1) Emin Üstünyurt \\ University of Health Sciences, Bursa Yüksek İhtisas Training and Research Hospital, Clinic of Obstetrics and Gynecology, Bursa, Turkey
}

\begin{abstract}
Objective: The relationship between hemoglobin levels and pregnancy outcomes is still a challenging issue. There is a supported opinion about the increased adverse pregnancy outcomes both with low and high hemoglobin levels. In this study, we aimed to evaluate this association for first trimester hemoglobin levels in a Turkish population.

Materials and Methods: In this retrospective study, 1306 women who were followed up during their pregnancy and gave birth in our clinic were enrolled. The patients were divided into three groups: hemoglobin $<11 \mathrm{~g} / \mathrm{dL}(\mathrm{n}=490), 11 \leq$ hemoglobin $<13 \mathrm{~g} / \mathrm{dL}$ ( $\mathrm{n}=673$ ), and hemoglobin $\geq 13 \mathrm{~g} / \mathrm{dL}$ ( $\mathrm{n}=143$ ). The hemoglobin $<11 \mathrm{~g} / \mathrm{dL}$ group was classified into two subgroups as hemoglobin $\leq 9 \mathrm{~g} / \mathrm{dL}$ ( $\mathrm{n}=64$ ) and hemoglobin $>9 \mathrm{~g} / \mathrm{dL}$ ( $\mathrm{n}=426$ ). Demographic characteristics, first trimester hemoglobin levels, gestational age at delivery and mode, birth weight, Apgar scores, and pregnancy outcomes were recorded and compared between the groups.

Results: Pregnancy-induced hypertension, preterm birth, neonatal intensive care unit admission, birth weight, gestational age at delivery, Apgar scores, and postpartum hemorrhage were significantly different between the three groups. In the pairwise comparison, gestational age at delivery, birth weight, and first minute Apgar scores were higher in the $11 \leq$ hemoglobin $<13 \mathrm{~g} / \mathrm{dL}$ group, and pregnancy-induced hypertension was more common in the hemoglobin $\geq 13$ g/dL group as compared with the others. Moreover, the preterm delivery rate was highest in the hemoglobin $\geq 13$ g/dL (26.6\%) group and lowest ( $7.3 \%$ ) in the $11 \leq$ hemoglobin $<13 \mathrm{~g} / \mathrm{dL}$ group. The neonatal intensive care unit admission rate was higher both the hemoglobin $<11 \mathrm{~g} / \mathrm{dL}$ and hemoglobin $\geq 13 \mathrm{~g} /$ dL groups. Postpartum hemorrhage was more common in the hemoglobin $<11$ g/dL group as compared with the other groups. Furthermore, pregnancyinduced hypertension was more common in the hemoglobin $\leq 9 \mathrm{~g} / \mathrm{dL}$ subgroup $(\mathrm{p}=0.012)$.
\end{abstract}

Conclusion: In conclusion, both low and high hemoglobin levels are related with adverse pregnancy outcomes. We suggest that hemoglobin levels must be screened during pregnancy to provide maternal and fetal well-being.

Keywords: First trimester, hemoglobin, pregnancy outcome

$\ddot{O} z$

Amaç: Hemoglobin seviyeleri ve gebelik sonuçları arasındaki ilişki halen çelişkili bir konudur. Hem yüksek hem de düşük hemoglobin seviyelerinde artan olumsuz gebelik sonuçları olduğuna dair kanıtlar bulunmaktadır. Bu çalışmada, Türk popülasyonunda ilk trimester hemoglobin seviyesi ve gebelik sonuçları ilişkisi değerlendirilmiştir.

Gereç ve Yöntemler: Bu retrospektif çalışmaya gebelik takipleri ve doğumu kliniğimizde gerçekleştirilen 1306 hasta dahil edildi. Hastalar hemoglobin $<11$ g/dL (n=490), $11 \leq$ hemoglobin <13 g/dL (n=673) ve hemoglobin $\geq 13$ g/dL (n=143) olmak üzere 3 gruba ayrlld. Hemoglobin <11 g/dL grubu da kendi içinde hemoglobin $\leq 9 \mathrm{~g} / \mathrm{dL}$ ( $\mathrm{n}=64$ ) ve hemoglobin $>9 \mathrm{~g} / \mathrm{dL}$ ( $\mathrm{n}=426$ ) olmak üzere 2 alt gruba ayrldd. Demografik özellikler, ilk trimester hemoglobin seviyeleri, doğum haftası, şekli ve kilosu, Apgar skorları ve gebelik sonuçları kaydedilerek gruplar arasında karşılaştırıldı.

Bulgular: Gebeliğin indüklediği hipertansiyon, preterm doğum, yenidoğan yoğun bakım ünitesi ihtiyacı, doğum kilosu, doğum haftası, Apgar skorları ve postpartum kanama sıklı̆̆ı üç grup arasında anlamlı olarak farklı idi. İkili grup karşılaştırmasında, doğum haftası, doğum ağırlı̆̆ ve birinci dakika Apgar skorlan $11 \leq$ hemoglobin $<13$ g/dL grubunda daha yüksek iken, gebeliğin indüklediği hipertansiyon hemoglobin $\geq 13$ g/dL grubunda diğer gruplardan daha sıtı. Ayrıca, preterm doğum hemoglobin $\geq 13$ g/dL grubunda en yüksek (26,6\%); $11 \leq$ hemoglobin $<13$ g/dL grubunda en düşük $(7,3 \%)$ oranda saptandı. Yenidoğan yoğun bakım ünitesi ihtiyacı hem hemoglobin $<11$ g/dL hem de hemoglobin $\geq 13$ g/dL grubunda daha yüksekti. Postpartum kanama, hemoglobin $<11 \mathrm{~g} / \mathrm{dL}$ grubunda diğer gruplara oranla daha sıktı. Ayrıca, gebeliğin indüklediği hipertansiyon hemoglobin $\leq 9 \mathrm{~g} / \mathrm{dL}$ alt grubunda daha sık olarak gözlendi $(\mathrm{p}=0,012)$.

Address for Correspondence/Yazışma Adresi: Burcu Dinçgez Çakmak, MD,

University of Health Sciences, Bursa Yüksek Ihtisas Training and Research Hospital, Clinic of Obstetrics and Gynecology, Bursa, Turkey

Phone: +90 5305448828 E-mail: burcumavis@gmail.com ORCID ID: orcid.org/0000-0002-2697-7501

Received/Geliş Tarihi: 08.05.2018 Accepted/Kabul Tarihi: 13.06.2018

${ }^{\circledR}$ Copyright 2018 by Turkish Society of Obstetrics and Gynecology

Turkish Journal of Obstetrics and Gynecology published by Galenos Publishing House. 
Sonuç: Sonuç olarak, hem düşük hem de yüksek hemoglobin seviyeleri olumsuz gebelik sonuçlaryyla ilişkilidir. Bu nedenle, maternal ve fetal iyilik halinin sağlanması için gebelikte hemoglobin seviyelerinin izlenmesi gerektiği kanaatindeyiz.

Anahtar Kelimeler: İlk trimester, hemoglobin, gebelik sonuçları

PRECIS: In this study, it is maintained that hemoglobin levels must be screened during pregnancy because both low and high hemoglobin levels are related with adverse pregnancy outcomes.

\section{Introduction}

Pregnancy has various effects on hematologic parameters. It is well known that hemoglobin $(\mathrm{Hb})$ levels decrease during the first trimester, reaching minimum values in the late second trimester and tend to increase during the third trimester of pregnancy ${ }^{(1)}$. Therefore cut-off levels for determining anemia differ from healthy reproductive women. The World Health Organization (WHO) defines anemia as Hb levels $<11.0 \mathrm{~g} /$ $\mathrm{dL}$ in the first and third trimesters and $<10.5 \mathrm{~g} / \mathrm{dL}$ in the second trimester in pregnant women ${ }^{(2)}$. Recently, there was a supported opinion about the relationship between anemia and adverse pregnancy outcomes. Several studies claimed that maternal anemia was risk factor for adverse pregnancy outcomes such as low birth weight (LBW), postpartum hemorrhage (PPH), cesarean section (CS), and preterm birth $(\mathrm{PB})^{(3)}$. Unfortunately, there are conflicting results about this issue. In another study, it was demonstrated that moderate or severe anemia was related with small-for-gestational-age infants, and patients with mild anemia were found to have uneventful pregnancy outcomes. Moreover, it was reported that preterm delivery and LBW were not increased in women with $\mathrm{Hb} 8-10.9 \mathrm{~g} / \mathrm{dL}^{(4)}$. Another interesting finding of the recent studies is the risk of adverse pregnancy outcomes in pregnancies with high $\mathrm{Hb}$ levels. In pregnancy, both total erythrocyte number and plasma volume increase, but $\mathrm{Hb}$ levels decrease according to the higher increment in plasma volume. This condition provides placental perfusion with reduced blood viscosity ${ }^{(5)}$. A high $\mathrm{Hb}$ concentration during pregnancy could result in placental infarcts due to the increased viscosity. As a consequence, these pregnancies can be complicated with pregnancy-induced hypertension (PIH), fetal growth restriction, and perinatal death ${ }^{(6)}$. The association between Hb levels and adverse pregnancy outcomes differs by trimesters. However, it is more evident in early pregnancy for low $\mathrm{Hb}$ levels, and it is evident in all trimesters for high $\mathrm{Hb}$ concentrations ${ }^{(7)}$. There are limited data about the relationship between adverse pregnancy outcomes and $\mathrm{Hb}$ levels in the first trimester of pregnancy in the Turkish population. In the present study, we evaluated the effect of first trimester $\mathrm{Hb}$ levels on pregnancy outcomes in our population.

\section{Materials and Methods}

This study was designed as a retrospective, observational, cross-sectional study. It was conducted in a universityaffiliated training and research hospital between January 2016 and May 2017. Ethics committee approval is unnecessary for retrospective studies in our country. Our study complies with the Declaration of Helsinki.

A total of 1306 women who were followed up during their pregnancy and gave birth in our clinic were enrolled in the study. First, patients were divided into three groups: $\mathrm{Hb}$ $<11 \mathrm{~g} / \mathrm{dL} \quad(\mathrm{n}=490), 11 \leq \mathrm{Hb}<13 \mathrm{~g} / \mathrm{dL} \quad(\mathrm{n}=673)$, and $\mathrm{Hb} \geq 13$ $\mathrm{g} / \mathrm{dL}(\mathrm{n}=143)$. Then, the $\mathrm{Hb}<11 \mathrm{~g} / \mathrm{dL}$ group was classified into two subgroups as $\mathrm{Hb} \leq 9 \mathrm{~g} / \mathrm{dL} \quad(\mathrm{n}=64)$ and $\mathrm{Hb}>9 \mathrm{~g} / \mathrm{dL}$ $(n=426)$. The exclusion criteria for patient selection were determined as follows; unregular antenatal visits, lack of delivery data, absence of first trimester $\mathrm{Hb}$ values, age $<16$ and $>40$ years, multiple pregnancies, congenital malformations, pregnancies with history of diabetes mellitus, hepatic and renal failure, thyroid diseases, any uterine malformations, previous complicated pregnancy, alcohol and cigarette use, any prior placental abnormalities and PPH. Demographic characteristics of the study population such as age, gravida, parity, and gestational age at delivery and birth weight were recorded. Also, first trimester Hb levels were obtained from medical records. In our hospital, $\mathrm{Hb}$ levels are determined using a Coulter LH780 Analyzer (Beckman Coulter Ireland Inc, Mervue, Galway, Ireland). Pregnancy outcomes were compared between the groups. The main perinatal outcomes were accepted as stillbirth, gestational diabetes mellitus (GDM), PIH, PB, neonatal intensive care unit (NICU) admission, PPH, CS, and low Apgar scores, and these outcomes were obtained from hospital records. Stillbirth was judged as the death of a fetus during delivery ${ }^{(8)}$. GDM was established as if one or more of the followings were increased in the $75 \mathrm{~g}$ oral glucose tolerance test: fasting glucose $\geq 92$ $\mathrm{mg} / \mathrm{dL}, \geq 180 \mathrm{mg} / \mathrm{dL}$ at 1 hour, and $\geq 153 \mathrm{mg} / \mathrm{dL}$ at 2 hours $^{(9)}$. $\mathrm{PIH}$ was named as systolic blood pressure $\geq 140 \mathrm{~mm} \mathrm{Hg}$ and/ or diastolic pressure $\geq 90 \mathrm{~mm} \mathrm{Hg}$ after the $20^{\text {th }}$ gestational week, and PB was defined as births that occured between the $24-37^{\text {th }}$ gestational weeks ${ }^{(10,11)}$. Neonates with shorter than 32 weeks of gestation, transient problems, cardiorespiratory monitoring requirement or presence of Respiratory Distress syndrome, severe jaundice, neonatal sepsis, and conditions requiring exchange transfusion were admitted to the NICU. PPH was defined as having a blood loss of $\geq 500 \mathrm{~mL}$ after vaginal delivery or $\geq 1000 \mathrm{~mL}$ after CS within 24 hours of delivery ${ }^{(12)}$.

\section{Statistical Analysis}

Statistical analyses were performed using the Statistical 
Package for the Social Sciences statistical software version 23.0 (SPSS, Chicago, IL). All data are reported as mean \pm standard deviation, median [minimum (min), maximum $(\max )]$ values or in percentages. The Shapiro-Wilk test and probability plots were used to evaluate whether the variables followed normal distribution. The chi-square test and Fisher's exact test were performed to evaluate the relationship between categorical variables. According to the normality test results, the Mann-Whitney U test was used for continuous non-normally distributed variables, and the independent t-test was used for continuous normally distributed variables to compare the variables between two groups. For comparing more groups, the non-parametric Kruskal-Wallis test was performed, and the Bonferroni-Dunn procedure was used to compare statistically significant parameters between two groups. Moreover, for normally distrubuted variables, oneway ANOVA analysis was performed to compare the variables between more than two groups. A $p$ value of $\leq 0.05$ was determined as statistically significant.

\section{Results}

The mean age of all study participants was $27.24 \pm 6.21$ years. The median gravida was $2(\min =1, \max =10)$ and parity was $1(\min =0, \max =8)$. The mean gestational age at delivery was $38.16 \pm 2.37$ weeks and the mean birth weight was $3134.78 \pm 600.96$ grams. The demographic data and pregnancy outcomes of three main groups were compared and are presented in Table 1. PIH, PB, NICU admission, birth weight, gestational age at delivery, Apgar scores, and PPH were significantly different between the three groups. In the pairwise comparison; gestational age at delivery, birth weight, and first-minute Apgar scores were significantly higher in $11 \leq \mathrm{Hb}<13 \mathrm{~g} / \mathrm{dL}$ group, and PIH was more common in the $\mathrm{Hb} \geq 13 \mathrm{~g} / \mathrm{dL}$ group as compared with the other groups. Moreover, the $\mathrm{PB}$ rate was highest in the $\mathrm{Hb} \geq 13 \mathrm{~g} / \mathrm{dL}$ (26.6\%) group and was lowest $(7.3 \%)$ in the $11 \leq \mathrm{Hb}<13 \mathrm{~g} / \mathrm{dL}$ group. The NICU admission rate was significantly higher in both the $\mathrm{Hb}<11 \mathrm{~g} / \mathrm{dL}$ and $\mathrm{Hb} \geq 13 \mathrm{~g} / \mathrm{dL}$ group as compared with the $11 \leq \mathrm{Hb}<13 \mathrm{~g} / \mathrm{dL}$ group. Furthermore, PPH was significantly more common in the $\mathrm{Hb}<11 \mathrm{~g} / \mathrm{dL}$ group as compared with the other groups. The comparison of demographic characteristics and pregnancy outcomes between the $\mathrm{Hb} \leq 9$ $\mathrm{g} / \mathrm{dL}$ and $9<\mathrm{Hb}<11 \mathrm{~g} / \mathrm{dL}$ group is shown in Table 2 . There was no difference between the two groups according to gravida, parity, age, gestational age at delivery, birth weight, Apgar scores, stillbirth, GDM, PB, CS, NICU admission, and PPH rates. Contrary to these, PIH was significantly higher in the $\mathrm{Hb} \leq 9 \mathrm{~g} / \mathrm{dL}$ group $(\mathrm{p}=0.012)$.

\section{Discussion}

The main findings of the study were as follows: PIH was more common in the high $\mathrm{Hb}$ group, and the incidences of $\mathrm{PB}$ and NICU admission were higher both in the high and low $\mathrm{Hb}$ groups. Moreover, PPH was common in the low Hb group. Gestational age at delivery, birth weight, and first-minute Apgar scores were significantly higher in the $11 \leq \mathrm{Hb}<13 \mathrm{~g} / \mathrm{dL}$ group, and there was no difference according to pregnancy outcomes between the very low and low Hb groups, except PIH. During pregnancy, many hormonal changes occur to provide adequate blood flow from the maternal to the fetal

Table 1. Demographic characteristics and pregnancy outcomes of all study groups

\begin{tabular}{|c|c|c|c|c|}
\hline & $\mathrm{Hb}<11 \mathrm{~g} / \mathrm{dL}(\mathrm{n}=490)$ & $11 \leq \mathrm{Hb}<13 \mathrm{~g} / \mathrm{dL}(\mathrm{n}=673)$ & $\mathrm{Hb} \geq 13 \mathrm{~g} / \mathrm{dL} \quad(\mathrm{n}=143)$ & $\mathrm{p}$ \\
\hline Age (years) & $26.97 \pm 6.07$ & $27.45 \pm 6.33$ & $27.17 \pm 6.12$ & 0.410 \\
\hline Gravida (n) & $2(1-8)$ & $2(1-10)$ & $2(1-9)$ & 0.887 \\
\hline Parity (n) & $1(0-5)$ & $1(0-7)$ & $1(0-8)$ & 0.465 \\
\hline Gestational age at delivery (week) & $37.78 \pm 2.62$ & $38.6 \pm 1.95$ & $37.43 \pm 2.8$ & $<0.001$ \\
\hline Birth weight (grams) & $2992.8 \pm 635.1$ & $3269.2 \pm 512.7$ & $2988.3 \pm 713.3$ & $<0.001$ \\
\hline Stillbirth (n, \%) & $8(1.6 \%)$ & $7(1.0 \%)$ & $3(2.1 \%)$ & 0.511 \\
\hline GDM $(n, \%)$ & $27(5.5 \%)$ & $35(5.2 \%)$ & $8(5.6 \%)$ & 0.965 \\
\hline PIH (n, \%) & $31(6.3 \%)$ & $23(3.4 \%)$ & $21(14.7 \%)$ & $<0.001$ \\
\hline Preterm birth (n, \%) & $78(15.9 \%)$ & $49(7.3 \%)$ & $38(26.6 \%)$ & $<0.001$ \\
\hline Cesarean section $(\mathrm{n}, \%)$ & $209(42.7 \%)$ & $259(38.5 \%)$ & $70(49.0 \%)$ & 0.051 \\
\hline NICU admission (n, \%) & $60(12.2 \%)$ & $36(5.3 \%)$ & $25(17.5 \%)$ & $<0.001$ \\
\hline Apgar $1^{\text {st }} \min$ & $8.69 \pm 1.37$ & $8.83 \pm 1.04$ & $8.65 \pm 1.44$ & 0.005 \\
\hline Apgar $5^{\text {th }} \min$ & $9.67 \pm 1.4$ & $9.81 \pm 1.08$ & $9.62 \pm 1.58$ & 0.012 \\
\hline PPH (n, \%) & $63(12.9 \%)$ & $37(5.5 \%)$ & $13(9.1 \%)$ & $<0.001$ \\
\hline
\end{tabular}

GDM: Gestational diabetes mellitus, Hb: Hemoglobin, NICU: Neonatal intensive care unit, PIH: Pregnancy-induced hypertension, PPH: Postpartum hemorrhage 
Table 2. Demographic characteristics and pregnancy outcomes of $\mathrm{Hb} \leq 9 \mathrm{~g} / \mathrm{dL}$ and $9<\mathrm{Hb}<11 \mathrm{~g} / \mathrm{dL}$ groups

\begin{tabular}{|c|c|c|c|}
\hline & $\mathrm{Hb} \leq 9 \mathrm{~g} / \mathrm{dL}(\mathrm{n}=64)$ & $9<\mathrm{Hb}<11 \mathrm{~g} / \mathrm{dL}(\mathrm{n}=426)$ & $\mathrm{p}$ \\
\hline Age (years) & $28.14 \pm 7.16$ & $26.79 \pm 5.88$ & 0.154 \\
\hline Gravida (n) & $2(1-7)$ & $2(1-8)$ & 0.600 \\
\hline Parity (n) & $1(0-5)$ & $1(0-4)$ & 0.832 \\
\hline $\begin{array}{l}\text { Gestational age at } \\
\text { delivery (week) }\end{array}$ & $37.56 \pm 2.51$ & $37.81 \pm 2.64$ & 0.291 \\
\hline Birth weight (grams) & $2958.5 \pm 617.3$ & $2997.9 \pm 638.2$ & 0.641 \\
\hline Stillbirth (n, \%) & $2(3.1 \%)$ & $6(1.4 \%)$ & 0.281 \\
\hline GDM (n, \%) & $3(4.7 \%)$ & $24(5.6 \%)$ & 0.999 \\
\hline PIH (n, \%) & $9(14.1 \%)$ & $22(5.2 \%)$ & 0.012 \\
\hline Preterm birth (n, \%) & $13(20.3 \%)$ & $65(15.3 \%)$ & 0.303 \\
\hline Cesarean section (n, \%) & $29(45.3 \%)$ & $180(42.3 \%)$ & 0.645 \\
\hline NICU admission (n, \%) & $10(15.6 \%)$ & $50(11.7 \%)$ & 0.376 \\
\hline Apgar $1^{\mathrm{st}} \min$ & $8.61 \pm 1.66$ & $8.7 \pm 1.32$ & 0.948 \\
\hline Apgar $5^{\text {th }} \min$ & $9.53 \pm 1.82$ & $9.69 \pm 1.33$ & 0.771 \\
\hline PPH (n,\%) & $8(12.5 \%)$ & $55(12.9 \%)$ & 0.927 \\
\hline
\end{tabular}

GDM: Gestational diabetes mellitus, Hb: Hemoglobin, NICU: Neonatal intensive care unit, PIH: Pregnancy induced hypertension, PPH: Postpartum hemorrhage

unit. One of these changes is increased plasma renin and decreased atrial natriuretic peptide levels. Also, erytropoetin secretion tends to increase and results in a rise in red blood cell mass. On the other hand, plasma volume expands nearly $50 \%$ and consequently, $\mathrm{Hb}$ levels decrease. Disturbance of these mechanism leads to hemoconcentration and high $\mathrm{Hb}$ levels ${ }^{(13,14)}$. PIH is still an important cause of maternal and fetal mortality and morbidity. Although the underlying mechanism has not been fully elucidated, recent studies have shown that increased $\mathrm{Hb}$ levels leading to vasoconstriction is one of the mechanisms of $\mathrm{PIH}^{(15)}$. Also, the loss of protein and increment in vascular permeability causes a decrement in intravascular volume and high $\mathrm{Hb}$ concentrations in preeclampsia ${ }^{(16)}$. In a study by Pritchard et al., ${ }^{(17)}$ the average hematocrit was higher in preeclampsia as compared with healthy pregnant women. In other studies, a significant relationship between high firsttrimester $\mathrm{Hb}$ levels and preeclampsia was demonstrated ${ }^{(18,19)}$. Similarly, in this present study, PIH was more common with high $\mathrm{Hb}$ levels. We and others suggest that the changes of hematologic changes in PIH start early in the first trimester and monitoring $\mathrm{Hb}$ levels could be used to follow up pregnancies at high risk for uteroplacental insufficiency.(20) Recent studies evaluating the PB risk in pregnant women in relation to $\mathrm{Hb}$ levels had conflicting results. Scanlon et al., (13) who divided the patient group into 7 levels as very low, low, low-normal, normal (reference group), high-normal, high, and very high $\mathrm{Hb}$ groups showed that patients with a firsttrimester $\mathrm{Hb}$ concentration below the reference range had an elevated risk of PTB. Furthermore, in a study of a Chinese population, elevated PB risk was found in the low firsttrimester $\mathrm{Hb}$ group ${ }^{(21,22)}$. On the other hand, no relationship was found between $\mathrm{PB}$ and first-trimester $\mathrm{Hb}$ levels in the study of Hamalainen et al. ${ }^{(23)}$. For high Hb levels, Zhang et al. ${ }^{(22)}$ found reduced risk for $\mathrm{PB}$, and other studies claimed that no association was present between $\mathrm{PB}$ and high $\mathrm{Hb}$ levels. ${ }^{(13,24)}$ Zhou et al. ${ }^{(25)}$ reported slightly increased risk for $\mathrm{PB}$ with high $\mathrm{Hb}$ levels. In this present study, $\mathrm{PB}$ rates were higher with both low and high Hb levels. Moreover, NICU admission rates were higher in both the high and low $\mathrm{Hb}$ groups, which could be related to prematurity and accompanying conditions. $\mathrm{PH}$ is one of the leading causes of maternal mortality. Oxygen and $\mathrm{Hb}$ transportation is the cornerstone of uterine contractions and it is claimed in the literature that anemic patients were more likely to experience uterine atony due to the absence of these mechanisms ${ }^{(26,27)}$. In the study of Sehgal et al., ${ }^{(4)}$ pregnant women with mild-tomoderate anemia were found to have more PPH. Similar to their study, we demonstrated that patients with $\mathrm{Hb}<11 \mathrm{~g} / \mathrm{dL}$ had more PPH as compared with those in the $11 \leq \mathrm{Hb}<13 \mathrm{~g} /$ $\mathrm{dL}$ and $\mathrm{Hb} \geq 13 \mathrm{~g} / \mathrm{dL}$ groups. There is no consensus about iron replacement, to whom and how many milligrams should be given in pregnancy. The WHO recommends $30-60 \mathrm{mg}$ daily iron during pregnancy. These data were based on the reduced risk of LBW with daily iron supplementation, increased risk for adverse effects, and adverse pregnancy outcomes for high $\mathrm{Hb}$ levels ${ }^{(28,29)}$. Supporting these recommendations, we found higher birth weights and Apgar scores, and lower PB in the $11 \leq \mathrm{Hb}<13 \mathrm{~g} / \mathrm{dL}$ group and we suggest that appropriate 
$\mathrm{Hb}$ levels with iron supplementation must be constituted to provide maternal and fetal well-being. However, we did not investigate the effects of iron supplementation on our pregnancy outcomes, which is one of the major limitations of our study. Another interesting finding of our study was that there was no difference with regard to pregnancy outcomes between the very low and low Hb groups, except PIH. A few studies that investigated the effects of severe or moderate anemia demonstrated that patients with moderate and severe anemia were more prone to uterine atony and $\mathrm{PPH}^{(26,27)}$. Pregnant women with mild anemia are generally expected to have uneventful pregnancies if well managed with iron supplementation ${ }^{(4)}$. Another study showed that $\mathrm{Hb}$ 8-10.9 g/dL was not associated with an increased PB and LBW risk $^{(22,30)}$. We suggest that our non-significant results between the very low and low Hb groups might be related to the small patient population with severe anemia.

\section{Study Limitation}

This study has several limitations. First, we did not investigate the effects of iron supplementation on our pregnancy outcomes. Second, we had small patient population with very low $\mathrm{Hb}$ levels to compare the pregnancy outcomes between low and very low $\mathrm{Hb}$ levels. Lastly, we only evaluated the first trimester $\mathrm{Hb}$ levels and it might be more appropriate to clarify the relationship between all trimester $\mathrm{Hb}$ levels and pregnancy outcomes.

\section{Conclusion}

In conclusion, both low and high $\mathrm{Hb}$ levels are related with adverse pregnancy outcomes. To provide maternal and fetal well-being, we must routinely screen the first trimester $\mathrm{Hb}$ levels and think about supplementing iron if it is appropriate.

\section{Ethics}

Ethics Committiee Approval: Retrospective study.

Informed Consent: Retrospective study.

Peer-review: External and internal peer-reviewed.

\section{Authorship Contributions}

Surgical and Medical Practices: B.D.Ç., E.Ü., Concept: B.D.Ç., Design: Ü.A.T., B.D.Ç., Data Collection or Processing: Ü.A.T., M.A., S.Ö., Analysis or Interpretation: M.A., S.Ö., E.Ü., Literature Search: B.D.Ç., S.Ö., Writing: B.D.Ç., E.Ü.

Conflict of Interest: No conflict of interest was declared by the authors.

Financial Disclosure: The authors declared that this study received no financial support.

\section{References}

1. Laflamme EM. Maternal hemoglobin concentration and pregnancy outcome: a study of the effects of elevation in El Alto, Bolivia. Mcgill J Med 2011;13:47.

2. 2.WHO/ UNICEF/UNO. IDA. Prevention, assessment and control. Report of a WHO/UNICEF/UNO Consultation. Geneva: WHO; 1998
3. Vural T, Toz E, Ozcan A, Biler A, Ileri A, Inan AH. Can anemia predict perinatal outcomes in different stages of pregnancy? Pak J Med Sci 2016;32:1354-9.

4. Sehgal R, Kriplani A, Vanamail P, Maiti L, Kandpal S, Kumar N. Assessment and comparison of pregnancy outcome among anaemic and non anaemic primigravida mothers. Indian J Public Health 2016;60:188-94

5. Mani S, Duffy TP. Anemia of pregnancy. Clin Perinatol 1995;22:593607.

6. Naeye RL. Placental infarction leading to fetal or neonatal death. A prospective study. Obstet Gynecol 1977;50:583-8.

7. Dewey KG, Oaks BM. U-shaped curve for risk associated with maternal hemoglobin, iron status, or iron supplementation. Am J Clin Nutr 2017;106:1694-702.

8. Kaur M, Chauhan A, Manzar D, Rajput MM. Maternal Anaemia and Neonatal Outcome: A Prospective Study on Urban Pregnant Women. J Clin Diagn Res 2015;9:QC04-8.

9. Sacks DB, Arnold M, Bakris GL, Bruns DE, Horvath AR, Kirkman MS, et al. Guidelines and recommendations for laboratory analysis in the diagnosis and management of diabetes mellitus. Clin Chem 2011;57:1-47.

10. Mancia G, Fagard R, Narkiewicz K, Redon J, Zanchetti A, Böhm M, et al. 2013 ESH/ESC guidelines for the management of arterial hypertension: the Task Force for the Management of Arterial Hypertension of the European Society of Hypertension (ESH) and of the European Society of Cardiology (ESC). Eur Heart J 2013;34:2159-219.

11. Di Renzo GC, Roura LC; European Association of Perinatal MedicineStudy Group on Preterm Birth. Guidelines for the management of spontaneous preterm labor. J Perinat Med 2006;34:359-66.

12. Nair M, Choudhury MK, Choudhury SS, Kakoty SD, Sarma UC, Webster $\mathrm{P}$, et al. Association between maternal anaemia and pregnancy outcomes: a cohort study in Assam, India. BMJ Global Health 2016;1:e000026.

13. Scanlon KS, Yip R, Schieve LA, Cogswell ME. High and low hemoglobin levels during pregnancy: differential risks for preterm birth and small for gestational age. Obstet Gynecol 2000;96:741-8.

14. Blackburn ST, Loper DL. Maternal, fetal, and neonatal physiology. A clinical perspective. Philadelphia: WB Saunders; 1992. P. 159-200.

15. Sarrel PM, Lindsay DC, Poole-Wilson PA, Collins P. Hypothesis: inhibition of endothelium-derived relaxing factor by haemoglobin in the pathogenesis of preeclampsia. Lancet 1990;336:1030-2.

16. Chappel L, Bewley S. Pre-eclamptic toxaemia: the role of uterine artery Doppler. Br J Obstet Gynaecol 1998;105:379-82.

17. Pritchard JA, Cunningham FG, Pritchard SA. The Pakland Memorial Hospital protocol for treatment of eclampsia: evaluation of 245 cases. Am J Obstet Gynecol 1984;148:951-63.

18. Aghamohammadi A, Zafari M, Tofighi M. High maternal hemoglobin concentration in first trimester as risk factor for pregnancy induced hypertension. Caspian J Intern Med 2011;2:194-7.

19. Murphy JF, O’Riordan J, Newcombe RG, Coles EC, Pearson JF. Relation of haemoglobin levels in first and second trimesters to outcome of pregnancy. Lancet 1986;1:992-5.

20. Vedernikov Y, Saade GR, Garfield RE. Vascular Reactivity in Preeclampsia. Semin Perinatol 1999;23:34-4.

21. Zhang Q, Ananth CV, Rhoads GG, Li Z. The impact of maternal anemia on perinatal mortality: a population-based, prospective cohort study in China. Ann Epidemiol 2009;19:793-9. 
22. Zhang Q, Ananth CV, Li Z, Smulian JC. Maternal anaemia and preterm birth: a prospective cohort study. Int J Epidemiol 2009;38:1380-9.

23. Hamalainen H, Hakkarainen K, Heinonen S. Anaemia in the first but not in the second or third trimester is a risk factor for low birth weight. Clin Nutr 2003;22:271-5.

24. Ren A, Wang J, Ye RW, Li S, Liu JM, Li Z. Low first-trimester hemoglobin and low birth weight, preterm birth and small for gestational age newborns. Int J Gynaecol Obstet 2007;98:124-8.

25. Zhou LM, Yang WW, Hua JZ, Deng CQ, Tao X, Stoltzfus RJ. Relation of hemoglobin measured at different times in pregnancy to preterm birth and low birth weight in Shanghai, China. Am J Epidemiol 1998;148:998-1006.

26. Kavle JA, Stoltzfus RJ, Witter F, Tielsch JM, Khalfan SS, Caulfield LE. Association between anaemia during pregnancy and blood loss at and after delivery among women with vaginal births in Pemba Island, Zanzibar, Tanzania. J Health Popul Nutr 2008;26:232-40.

27. Malhotra M, Sharma JB, Batra S, Sharma S, Murthy NS, Arora R. Maternal and perinatal outcome in varying degrees of anemia. Int J Gynaecol Obstet 2002;79:93-100.

28. WHO Guideline: daily iron and folic acid supplementation in pregnant women. Geneva Switzerland: WHO; 2012.

29. Pena-Rosas JP, De-Regil LM, Garcia-Casal MN, Dowswell T. Daily oral iron supplementation during pregnancy. Cochrane Database Syst Rev 2015:CD004736.

30. Yi SW, Han YJ, Ohrr H. Anemia before pregnancy and risk of preterm birth, low birth weight and small for gestational age birth in Korean women. Eur J Clin Nutr 2013;67:337 42. 